International Journal of English Literature and Social Sciences
Vol-6, Issue-1; Jan-Feb, 2021
Journal Home Page Available: https://ijeab.com/
Journal DOI: $10.22161 / \mathrm{ijels}$

\title{
Emotional Exhaustion among Hospitality and Tourism Professionals in Cabanatuan City: Basis for Retraining
}

\author{
Kelvin Julius A. Nueda
}

Hospitality Management and Tourism Major, Nueva Ecija University of Science and Technology, College of Management and Business Technology, Philippines

Received: 02 Dec 2020; Received in revised form: 22 Jan 2021; Accepted: 09 Feb 2021; Available online: 16 Feb 2021

(C)2021 The Author(s). Published by Infogain Publication. This is an open access article under the CC BY license

(https://creativecommons.org/licenses/by/4.0/).

\begin{abstract}
New research suggests we work more effectively, creatively, and collaboratively when we are happy at work. The brain works much better when a person is feeling positive. At those times, individuals tend to be more inspired and better at solving problems. This study was intended to determine the emotional exhaustion among hospitality and tourism professionals in Cabanatuan City and suggest an employee development plan to lessen the exhaustion experienced by the employees but otherwise perform their job satisfactorily, which will benefit both the employee and the establishments as well as the guests. The study adopted the descriptive method of research that involved survey from different hospitality and tourist establishments such as hotels, restaurants, and coffee shops within the premises of Cabanatuan City. One hundred employees from different hospitality and tourist establishments were subjected to answer questionnaires reflecting their level of exhaustion regarding negative thoughts and feelings, time pressure, strained relationship, counter productive work/behavior, length of service and salary. It was done using an evaluation sheet to rank and determine the greatest exhaustion level prevailing and answer the question of the researcher. The result of the study showed that length of experience and salary greatly affects the emotional exhaustion of the employees. The negative signs mean that the lower the length of experience and monthly income, the higher the emotional exhaustion of the employee. People from the hospitality industry sometimes feel emotionally exhausted due to the negative feelings they get from their job. Strained relationships, oftentimes, caused employees in the hospitality industry to be emotionally exhausted especially when talking of respect and conflicts. The study deemed that it is essential for employers to provide retraining programs to their emotionally exhausted employees. At the same time, employees affected with emotional exhaustion are recommended to undergo holistic interventions.
\end{abstract}

Keywords - Hospitality Industry, emotional exhaustion, turnover, retraining.

\section{INTRODUCTION}

From the employees of the hotels and casinos of Metro Manila and the stewards working on ocean liners to the solitary chefs in small town eateries and the servers in the restaurants of the growing industry in Cabanatuan City who are people working in the hospitality industry, emotional exhaustion is a serious and common problem. Emotional exhaustion or burnout is one of the constraints of a job performance especially in the tourism and hospitality industry with a $24 / 7$ nature of the hotel business as well as the round-the-clock guest service which demands hospitality industry employees to perform their jobs on a frequently stressful environment.

In the hospitality industry, the customers pay not only for the tangible products like food, beverage, hotel rooms and facilities but also the intangible product which is the service rendered by the people in the organization. A coffee shop may serve a cup of coffee may double or triple its price because of the excellent service rendered by the staff. People working in the industry need not only their 
physical vigor but emotional strength and mental determination as well. Establishments offering good food and luxurious hotel rooms without excellent service are useless. It is very important that the hotel or restaurant staff should be emotionally stable in order for them to bear exceptional services.

The researcher decided to conduct this study to determine the causes and effect of emotional exhaustion among the employees in the hospitality industry of Cabanatuan City. The researcher believes that it would be a great help to the owners, employees and the whole establishment if they found out what causes the emotional exhaustion so they can conduct some training or motivation program that will help the industry workers to render exceptional and excellent service and decrease the rate of employee turnover.

\section{STATEMENT OF THE PROBLEM}

This study aimed to determine the emotional exhaustion experienced by the hospitality and tourism professionals.

Specifically, the study sought to answer the following questions:

1. How may the profile of the respondents be described in terms of:
$1.1 \quad$ Age;
1.2 Gender;
1.3 Civil Status;
1.4 Highest Educational Attainment;
1.5 Work Experience;
1.5.1 Length of service in the industry;
1.5.2 Position in the organization;
1.5.3 Department;
1.5.3.1 Hotel;
1.5.3.2 Restaurant / Coffee Shop; and
1.5.4. Monthly Income?

2. What is the level of emotional exhaustion among hospitality and tourism professionals in terms of:
2.1 Negative feelings and thoughts;
2.2 Time Pressure;
2.3 Strained Relationships;
2.4 Counter Productive Work / Behavior;

3. Is there a significant relationship between the profile of the respondents and their level of emotional exhaustion? 4. What emotional training program may be proposed by the researcher as an output of this study?

\section{RESEARCH METHODOLOGY}

The researcher employed a descriptive method of research to describe the profile of the respondents and to look into their professional qualifications. This method was also used to identify the factors that influence hospitality and tourism professionals to experience burnout in terms of negative feelings and thoughts, time pressure, strained relationship and counter - productive work/behavior that lead to emotional exhaustion among hospitality and tourism professionals and their significant relationship if there is any.

This study was conducted in different hospitality and tourist establishments such as hotels, restaurants, and coffee shops within the premises of Cabanatuan City.

The questionnaire was used to gather data such as the factors that influence hospitality and tourism professionals to experience burnout in terms of negative feelings and thoughts, time pressure, strained relationship and counterproductive work/ behavior among hospitality and Tourism professionals was patterned from Maslach's MBI (Maslach Burnout Inventory).

In the questionnaire, the employees were asked to supply the information called for.

The researcher personally administered the instrument to the respondents after seeking permission from the management of each establishments, particularly the

owners and or the managers. The researcher set an appointment to the management regarding the schedule of interview.

Table 1: Respondents Distribution of the Hospitality and Tourism Professionals in Cabanatuan City

\begin{tabular}{|l|l|}
\hline Name of the Establishment & $\begin{array}{l}\text { Number of } \\
\text { Employees }\end{array}$ \\
\hline Harvest Hotel & 10 \\
\hline Microtel Hotel & 10 \\
\hline Royal Crest Hotel & 10 \\
\hline Café La Tea NE Pacific Mall & 5 \\
\hline Bistro 360 & 5 \\
\hline Hap Chan Restaurant & 10 \\
\hline Kenny Rogers Roasters & 5 \\
\hline Cabalen Restaurant & 10 \\
\hline Gerry's Grill SM City & 5 \\
\hline Rustica Restaurant & 10 \\
\hline Pizza Hut NE Pacific Mall & 10 \\
\hline Shakey's Pizza & 10 \\
\hline Total & $\mathbf{1 0 0}$ \\
\hline
\end{tabular}

The researcher took the opportunity to gather information during those schedules that the respondents of 
the selected hospitality and tourism industry were on available time to avoid disruption of the operation. Respondents were chosen because of their convenient accessibility and proximity to the researcher, which exclude the possibility of completing the $100 \%$ or full file of the all the employees working in the selected tourism and hospitality industry in Cabanatuan City.

The respondents were the ones who assessed their level of emotional exhaustion because they were the ones who know what they really feel.

\section{RESULTS AND DISCUSSION}

This part presented the results and findings of the study based on the gathered data.

Demographic Profile of the Respondents

Table 2: Profile of the Respondents

\begin{tabular}{|l|l|l|}
\hline \multicolumn{1}{|c|}{ Age } & Frequency(f) & Percent(\%) \\
\hline $20-29$ & 77 & 77.0 \\
\hline $30-39$ & 22 & 22.0 \\
\hline $40-49$ & 1 & 1.0 \\
\hline Total Gender & 100 & 100.0 \\
\hline & Frequency(f) & Percent(\%) \\
\hline Male & 47 & 47.0 \\
\hline Female & 53 & 53.0 \\
\hline Total & 100 & 100.0 \\
\hline \multicolumn{1}{|c|}{ Civil Status } & Frequency(f) & Percent(\%) \\
\hline Single & 73 & 73.0 \\
\hline Married & 27 & 27.0 \\
\hline Total & 100 & 100.0 \\
\hline Educational Attainment & Frequency(f) & Percent(\%) \\
\hline Bachelor's Degree & 99 & 99.0 \\
\hline Master's Degree & 1 & 1.0 \\
\hline Total & 100 & 100.0 \\
\hline \multicolumn{1}{|c|}{ Length of Service } & Frequency(f) & Percent(\%) \\
\hline Less than a year & 35 & 35.0 \\
\hline 1-5 years & 50 & 50.0 \\
\hline $\begin{array}{l}\text { More than 5 years but } \\
\text { less than 10 years }\end{array}$ & 7 & 7.0 \\
\hline $\begin{array}{l}\text { More than 10 years but } \\
\text { less than 15 years }\end{array}$ & 3 & 3.0 \\
\hline 16 years and above & 5 & 5.0 \\
\hline Total Position & 100 & 100.0 \\
\hline & Frequency(f) & Percent(\%) \\
\hline Owner & 13 & 1.0 \\
\hline Manager & 14 & 13.0 \\
\hline Supervisor & 72 & 72.0 \\
\hline Rank and File & \\
\hline
\end{tabular}

Table 2 shows the profile of the respondents. In terms of age, it can be seen from the table that $77 \%$ belongs to the age range of 20-29 followed by the respondents ranging from ages 30-39 which consist of $22 \%$ and the least was in the age range of 40-49 which got the total average of $1 \%$.

The data revealed that most of the hospitality workers are considered young adult.

According to Erik Erikson's Stages of Human Development (Bayani, 2009), Young adulthood can be considered the healthiest time of life and generally in good health. They have the physical strength and stamina to carry out the strenuous and draining job in the hospitality and restaurant industry. Moreover, many young adults choose the hospitality industry for the reason that there is the potential for rapid horizontal movement. Young individuals can make their way up the ladder very quickly if they work hard and provided that they possessed the qualifications.

In terms of gender, the table reveals that $53 \%$ of the respondents are female and $47 \%$ comprises the male respondents.

This evidently showed that the majority of the employees working in the hospitality industry in Cabanatuan City are female. This is also congruent to the National Statistics data of working Filipinos in 2014 which stressed that female workers are significantly higher by $6.23 \%$ than 
male counterparts in industries of education, communication technology, business, marketing and hospitality and tourism.

In terms of civil status, the data in Table 2 shows that $73 \%$ of the respondents are unmarried or single respondents and $27 \%$ are married respondents. The data indicated that out of 100 respondents, 73 workers in the hospitality industry of Cabanatuan City are single or not married.

In congruence to the age of the respondents, they are not yet married. They are the young adults who are in their early adulthood stage wherein they fall from late teenage years until their early twenties. Young adult nowadays does not settle yet in marriage and the responsibility of having a family. They tend to focus first on their career.

In terms of highest educational attainment, it was found out that ninety-nine (99) out of 100 respondents have a Bachelor's Degree and only one (1) respondent have managed to finish a Master's Degree.

The educational requirements for a career as hospitality worker include a bachelor's degree. In some cases, a high school or associate degree may be enough (Learn.org). But if the worker wanted to have managerial or other related higher position, he should be a bachelor's diploma holder and significant trainings.

In terms of length of service in the industry, Table 2 shows that respondents working for 1-5 years got the highest percentage of $50 \%$ followed by respondents working for less than a year with $35 \%$. Respondents working for more than 5 years but less than 10 years and more than 10 years but less than 15 years followed with $7 \%$ and $3 \%$ respectively. However, $5 \%$ of the respondents have been working for more than 16 years.

It was observed that very few employees spend their professional life as employees in hospitality and tourism industry. Most of them go abroad after some years of experience in the Philippines while some of them try other options like entrepreneurship or other line of industry. To sum it all, most of the respondents take the Philippines as their training ground to gain experience for future immersion into other countries.

"Kumukuhalangako ng experience dito

saPilipinastapos mag-a-abroad din ako."

In terms of their position in the organization, Table 2 also presents that $72 \%$ of the respondents belong to the Rank and File employees followed by supervisors with $14 \%$. Thirteen (13) percent are Managers and only one (1) respondent is the owner.
In terms of the department where they belong, Table 2 indicates that respondents are mostly from the Dining Area with $42 \%$ and Kitchen of a restaurant with $15 \%$ respectively. This was followed by Front Office with $9 \%$. Eight (8) percent of the respondents are from the Hotel's Housekeeping department and Restaurant's Host/Receptionist Area. Respondents from the Hotel's Food and Beverage Department occupies $7 \%$ while $6 \%$ came from the Reservation Department and the Administrative Department with $4 \%$. And, $1 \%$ of the respondents belong the Purchasing department.

Lastly, in terms of monthly income, Table 2 evidently showed that among hospitality professionals, 52\% of the respondents received P5,000 - P10,000 per month. $16 \%$ of the respondents received P11,000 - P15,000 while $12 \%$ of the respondents receive a salary of $\mathrm{P} 4,000$ below per month. Only $9 \%$ of the respondents received P16,000 P20,000.

In line with Maroudas, Kyriakidou, and Vacharis (2008) research, the effects of incentives on their employees in the luxury hotel setting of Athens, Greece. The participants were given a questionnaire that asked hotel identity, biographical data, and motivators used. The questions that were asked pertained to a list of incentives that were offered to the employees which included, but was not limited to: gifts, bonuses, paid expenses to seminars, meals, transfers, events, and insurance (Maroudas et al., 2008). This research enhanced previous research done which stated that there is a link to employee motivators (such as incentives) and an overall employee's performance. The study also recommends 11 future research on the effects of training programs on employee morale (Maroudas et al., 2008)

Sub Problem No. 2. What is the level of emotional exhaustion of the respondents in terms of:

2.1. Negative feelings and thoughts;

Table 3: Emotional Exhaustion of Respondents in terms of Negative Feelings and Thoughts

\begin{tabular}{|l|l|l|}
\hline $\begin{array}{l}\text { Negative Feelings and } \\
\text { Thoughts }\end{array}$ & $\begin{array}{l}\text { W } \\
\mathbf{M}\end{array}$ & $\begin{array}{l}\text { Verbal } \\
\text { Description }\end{array}$ \\
\hline $\begin{array}{l}\text { 1. I feel exhausted holistically } \\
\text { when I arrived home after } \\
\text { work. }\end{array}$ & 2.56 & Often \\
\hline $\begin{array}{l}\text { 2. I feel I can't stand this job } \\
\text { even one more day. }\end{array}$ & 1.65 & Never \\
\hline $\begin{array}{l}\text { 3. I am of the opinion that my } \\
\text { job puts limitations on me. }\end{array}$ & 1.83 & Sometimes \\
\hline
\end{tabular}




\begin{tabular}{|l|l|l|}
\hline $\begin{array}{l}\text { 4. I feel I get exhausted at work } \\
\text { both emotionally and } \\
\text { cognitively. }\end{array}$ & 2.40 & Sometimes \\
\hline $\begin{array}{l}\text { 5. I believe that I become } \\
\text { useless through my job. }\end{array}$ & 1.47 & Never \\
\hline $\begin{array}{l}\text { 6. I feel that I create an } \\
\text { environment in which the } \\
\text { customers and co-workers feel } \\
\text { uncomfortable at work. }\end{array}$ & 1.73 & Never \\
\hline $\begin{array}{l}\text { 7. I feel that success in my } \\
\text { profession is somehow near yet } \\
\text { so far. }\end{array}$ & 2.02 & Sometimes \\
\hline $\begin{array}{l}\text { 8. I feel I got senseless towards } \\
\text { people since I started this job. }\end{array}$ & 1.70 & Never \\
\hline $\begin{array}{l}\text { 9. I am worried that my job } \\
\text { makes me hard - hearted and } \\
\text { hard - headed. }\end{array}$ & 1.65 & Never \\
\hline $\begin{array}{l}\text { 10. I do not get a feeling of } \\
\text { accomplishment from my job. }\end{array}$ & 2.30 & Sometimes \\
\hline Overall Weighted Mean & 1.93 & Sometimes \\
\hline
\end{tabular}

Legend: 1:00-1.74 Never (Not Stressful); 1.75 - 2.49 Sometimes (Moderately Stressful); 2.50 - 3.24 Often (Very Stressful); 3.25 - 4:00 Always (Extremely Stressful)

Table 3 presents the negative feelings and thoughts of the hospitality workers in Cabanatuan City. 59 of the respondents feel holistically exhausted upon coming home from work. This means that their job is "very stressful" for them. This may be caused by several factors lead to their exhaustion such as heavy workload in terms of customer/guest accommodation, side duties, heavy kitchen responsibilities and others. An interview with one of the respondents, she clearly stated:

"Nakakapagod ang trabahonamindito, physically and emotionally.

Pagdatingmo ng bahaywala ka nanglakas para gawin pa ang ibangtrabaho. Nakakaubostalaga ng energy."

-Tracy, 24 Harvest Hotel

Majority of the respondents said that they are emotionally exhausted in their work which means that their work is "moderately stressful" for them while 66 out of 100 respondents considered quitting their job is "not stressful" for them because of the personal and professional fulfilment they get from their job.

Table 3 evidently exhibited that the overall weighted mean was 1.93 with verbal description of "moderately stressful". People from the hospitality industry sometimes feel emotionally exhausted due to the negative feelings they get from their job. According to Ann Blackburn of the Hotel

Industry Magazine, employees with negative emotions damage team morale and performance, destroy the guest experience and the establishment's reputation. The employee's negative emotions inevitably end up at your door as a complaint.

\subsection{Time Pressure;}

Table 4: Emotional Exhaustion of Respondents in terms of Time Pressure

\begin{tabular}{|c|c|c|}
\hline Time Pressure & WM & Verbal Description \\
\hline $\begin{array}{l}\text { 1. I feel exhausted when } \\
\text { reporting to duty ahead of } \\
\text { time. }\end{array}$ & 2.50 & Often \\
\hline $\begin{array}{l}\text { 2. I feel exhausted when I } \\
\text { have to stay to work beyond } \\
\text { my official time. }\end{array}$ & 1.86 & Sometimes \\
\hline $\begin{array}{l}\text { 3. I feel exhausted when } \\
\text { making a list of things which } \\
\text { are needed to do. }\end{array}$ & 1.82 & Sometimes \\
\hline $\begin{array}{l}\text { 4. I feel exhausted in being } \\
\text { able to keep busy during duty. }\end{array}$ & 1.79 & Sometimes \\
\hline $\begin{array}{l}\text { 5. I feel exhausted when } \\
\text { responding to problems / } \\
\text { issues immediately which } \\
\text { needed my judgement. }\end{array}$ & 2.51 & Often \\
\hline $\begin{array}{l}\text { 6. I feel exhausted when doing } \\
\text { something that makes use of } \\
\text { abilities. }\end{array}$ & 1.72 & Never \\
\hline $\begin{array}{l}\text { 7. I feel exhausted when } \\
\text { delegating tasks to others in } \\
\text { accomplishing a task. }\end{array}$ & 1.79 & Sometimes \\
\hline $\begin{array}{l}\text { 8. I feel exhausted when } \\
\text { developing a rapport with my } \\
\text { co-workers and superiors. }\end{array}$ & 1.77 & Sometimes \\
\hline $\begin{array}{l}\text { 9. I feel exhausted when } \\
\text { responding to customers' } \\
\text { immediate needs and requests. }\end{array}$ & 1.67 & Never \\
\hline $\begin{array}{l}\text { 10. I feel exhausted when } \\
\text { doing different things from } \\
\text { time to time. }\end{array}$ & 1.76 & Sometimes \\
\hline Overall Weighted Mean & 1.92 & Sometimes \\
\hline
\end{tabular}

Legend: 1:00-1.74 Never (Not Stressful); 1.75 - 2.49 Sometimes (Moderately Stressful); 2.50 - 3.24 Often (Very Stressful); 3.25 - 4:00 Always (Extremely Stressful)

Table 4 demonstrates that majority or 51 respondents feel emotionally exhausted when their job 
requires them to immediately respond, troubleshoot or solve problems. For them, this is "very stressful" due to some reasons like they do not want to get involved in the problem because that had enough from outside their work or they cannot think of immediate solutions to the problems that occurred. While majority of them emotionally exhausted when reporting to duty ahead of time, 44 respondents answered that they also feel exhausted when they are staying at work beyond their official time of duty and this is considered "moderately stressful" for them. And showing that it is "not stressful", only 4 out of 100 employees are emotionally exhausted when responding to customers' needs which means that greater respondents are attending to guests' needs and requests happily and satisfactorily.

The overall weighted mean for Table 4 is 1.92 with a verbal description of "moderately stressful". According to Zohar and Monachello (1996), one of the contributing factors to high level of stress among hospitality and industry workers is the long hours of work. Numerous studies by Marianna Virtanen of the Finnish Institute of Occupational Health and her colleagues have found that long hours of work results to stress that can lead to all sorts of health problems including impaired sleep, depression, impaired memory and heart disease.

\subsection{Strained relationships; and}

Table 5: Emotional Exhaustion of Respondents in terms of Strained Relationships

\begin{tabular}{|l|l|l|}
\hline Strained Relationships & WM & Verbal Description \\
\hline $\begin{array}{l}\text { 1. I am exhausted through the } \\
\text { way promotions are given out } \\
\text { on this job. }\end{array}$ & 1.77 & Sometimes \\
\hline $\begin{array}{l}\text { 2. I am exhausted through the } \\
\text { way company policies are put } \\
\text { into practice. }\end{array}$ & 1.79 & Sometimes \\
\hline $\begin{array}{l}\text { 3. I am exhausted through the } \\
\text { way I am noticed when I do a } \\
\text { good job affects others. }\end{array}$ & 1.71 & Never \\
\hline $\begin{array}{l}\text { 4. I am exhausted when the } \\
\text { competence of my supervisor } \\
\text { in making decisions affects } \\
\text { my job performance. }\end{array}$ & 1.83 & Sometimes \\
\hline $\begin{array}{l}\text { 5. I am exhausted through the } \\
\text { way my supervisors handle } \\
\text { conflicts among employees. }\end{array}$ & 1.80 & Sometimes \\
\hline $\begin{array}{l}\text { 6. I am exhausted when } \\
\text { insensitivity arises when } \\
\text { somebody acts as a leader } \\
\text { among others. }\end{array}$ & 1.80 & Sometimes \\
\hline
\end{tabular}

\begin{tabular}{|c|c|c|}
\hline $\begin{array}{l}\text { 7. I am exhausted when } \\
\text { respect between and among } \\
\text { members of the team is } \\
\text { jeopardize when a certain } \\
\text { conflict occurs. }\end{array}$ & 2.53 & Often \\
\hline $\begin{array}{l}\text { 8. I am exhausted when } \\
\text { workforce circulation is } \\
\text { affected by conflicts between } \\
\text { supervisors - rank and file; } \\
\text { co-workers - co- workers. }\end{array}$ & 2.51 & Often \\
\hline $\begin{array}{l}\text { 9. I am exhausted when the } \\
\text { commitment to organization } \\
\text { is affected when conflict } \\
\text { occurs. }\end{array}$ & 1.70 & Never \\
\hline $\begin{array}{l}\text { 10. I am exhausted when job } \\
\text { satisfaction, problem solving } \\
\text { skills and high health } \\
\text { expenses suffer from a } \\
\text { miscommunication } \\
\text { misunderstanding in the } \\
\text { workplace. }\end{array}$ & 1.89 & Sometimes \\
\hline Overall Weighted Mean & 1.93 & Sometimes \\
\hline
\end{tabular}

Table 5 displayed that oftentimes, employees in the hospitality industry are emotionally exhausted when talking of respect and conflicts. 41 out of 100 respondents said that they are emotionally exhausted when conflicts and disrespect arise among the members of the team. This is verbally explained as "very stressful". Conflicts may occur if there is disagreement among the members of the team, which if not resolved may lead to negative attributes such as disrespect.

The overall weighted mean for table 2.3 is 1.93 with verbal description of "moderately stressful".

\subsection{Counter productive work/behavior?}

Table 6: Emotional Exhaustion of Respondents in terms of Counter Productive Work / Behavior

\begin{tabular}{|l|l|l|}
\hline \multicolumn{1}{|c|}{ Counter Productive Work } & WM & $\begin{array}{l}\text { Verbal } \\
\text { Description }\end{array}$ \\
\hline $\begin{array}{l}\text { 1. I feel that I have lost my } \\
\text { enthusiasm about my } \\
\text { profession. }\end{array}$ & 1.50 & Never \\
\hline $\begin{array}{l}\text { 2. It is really tiring for me to } \\
\text { deal with people all day long. }\end{array}$ & 1.63 & Never \\
\hline $\begin{array}{l}\text { 3. It makes me stressful to be in } \\
\text { a direct communication with } \\
\text { people. }\end{array}$ & 1.54 & Never \\
\hline
\end{tabular}




\begin{tabular}{|l|l|l|}
\hline $\begin{array}{l}4 . \text { I cannot get how the } \\
\text { customers feel easily. }\end{array}$ & 1.92 & Sometimes \\
\hline $\begin{array}{l}\text { 5. I believe that energy and } \\
\text { enthusiasm is always needed at } \\
\text { my job. }\end{array}$ & 2.26 & Sometimes \\
\hline $\begin{array}{l}\text { 6. I do not feel active and } \\
\text { vigorous while I am working. }\end{array}$ & 2.20 & Sometimes \\
\hline $\begin{array}{l}\text { 7. I feel that growth in this } \\
\text { profession is neither gradually } \\
\text { nor fast. }\end{array}$ & 2.09 & Sometimes \\
\hline $\begin{array}{l}\text { 8. I cannot overcome my } \\
\text { emotional problems when } \\
\text { reporting to work. }\end{array}$ & 2.08 & Sometimes \\
\hline $\begin{array}{l}\text { 9. I feel I behave insensitively } \\
\text { to the customers, co-workers } \\
\text { and superiors. }\end{array}$ & 2.04 & Sometimes \\
\hline $\begin{array}{l}\text { 10. I do not care about the } \\
\text { problems/issues of the } \\
\text { customers, my co-workers and } \\
\text { superiors. }\end{array}$ & 1.78 & Sometimes \\
\hline Overall Weighted Mean & 1.90 & Sometimes \\
\hline
\end{tabular}

Legend: 1:00-1.74 Never (Not Stressful); 1.75 - 2.49 Sometimes (Moderately Stressful); 2.50 - 3.24 Often (Very Stressful); 3.25 - 4:00 Always (Extremely Stressful)

Table 6 indicated that 37 respondents pointed out that energy and enthusiasm are the qualifications they must possess when working in the hospitality industry which in the survey, turned out to be "moderately stressful" for them. It is not all the time that a person or employee can possess these attitude or behavior. There are times employees are not eager and energetic due to some factors that includes tiredness, personal problems, sickness and lack of sleep. This may lead to emotional dissonance wherein an employee is still smiling in front of the customers even though they are not feeling well in the inside. Though being enthusiastic and energetic cause employees' stress, there are still 67 respondents answered that even though they are moderately stressed when reporting to work eagerly, they still do not lose their enthusiasm towards their work. It is still "not stressful" to be dedicated to their profession.

Table 6 has a total weighted mean of 1.90 with verbal interpretation of "moderately stressful".

Table 7: Summary Table

\begin{tabular}{|l|c|l|}
\hline Variables & WM & Verbal Description \\
\hline $\begin{array}{l}\text { 1. Negative feelings and } \\
\text { thoughts }\end{array}$ & 1.93 & Sometimes \\
\hline 2. Time Pressure & 1.92 & Sometimes \\
\hline
\end{tabular}

\begin{tabular}{|l|l|l|}
\hline 3. Strained Relationship & 1.93 & Sometimes \\
\hline $\begin{array}{l}\text { 4. Counter Productive } \\
\text { work/behavior }\end{array}$ & 1.90 & Sometimes \\
\hline
\end{tabular}

Legend: 1:00-1.74 Never (Not Stressful); 1.75 - 2.49 Sometimes (Moderately Stressful); 2.50 - 3.24 Often (Very Stressful); 3.25 - 4:00 Always (Extremely Stressful)

Sub Problem No. 3. Is there a significant relationship between the profile of the respondents and their level of emotional exhaustion?

Table 8: Correlation of Profile of Respondents and their Emotional Exhaustion

\begin{tabular}{|l|l|l|l|}
\hline Variables & $\begin{array}{l}\text { Emotional } \\
\text { Exhaustion, } \\
\text { value }\end{array}$ & $\begin{array}{l}\text { p- } \\
\text { valu } \\
\mathbf{e}\end{array}$ & Interpretation \\
\hline Age & -.014 & .887 & $\begin{array}{l}\text { No significant } \\
\text { relationship }\end{array}$ \\
\hline Civil Status & -.056 & .578 & $\begin{array}{l}\text { No significant } \\
\text { relationship }\end{array}$ \\
\hline Gender & -.068 & .500 & $\begin{array}{l}\text { No significant } \\
\text { relationship }\end{array}$ \\
\hline $\begin{array}{l}\text { Educational } \\
\text { Attainment }\end{array}$ & -.077 & .445 & $\begin{array}{l}\text { No significant } \\
\text { relationship }\end{array}$ \\
\hline $\begin{array}{l}\text { Length of } \\
\text { Experience }\end{array}$ & $-.210^{*}$ & .036 & $\begin{array}{l}\text { Significant } \\
\text { relationship }\end{array}$ \\
\hline Position & .029 & .776 & $\begin{array}{l}\text { No significant } \\
\text { relationship }\end{array}$ \\
\hline Department & .052 & .605 & $\begin{array}{l}\text { No significant } \\
\text { relationship }\end{array}$ \\
\hline Salary & $-.208^{*}$ & .038 & $\begin{array}{l}\text { Significant } \\
\text { relationship }\end{array}$ \\
\hline
\end{tabular}

*correlation is significant @ 0.05 level

Table 7 shows that age has no significant relationship in the emotional exhaustion of the hospitality and tourism employees as well as the civil status, educational attainment, gender, position in the organization, and the department they belong with.

Relative to the study of Ogaard et al. (2008), middle and senior level managers in hotel enterprises and first-class holiday villages in an effort to determine their job satisfaction levels, it was demonstrated that managers had exceptionally high job satisfaction level despite heavy working conditions.

Length of experience and salary greatly affects the emotional exhaustion of the employees. The negative signs mean that the lower the length of experience and monthly income, the higher the emotional exhaustion of the employee. 
Congruent to the study conducted by Varona (1996) on the relationship between communication satisfaction and organizational commitment in three Guatemalan organizations, it was found out that employees with more tenure status were significantly more committed to their organization. Older workers seem report higher levels of job satisfaction than younger ones. This means that if there is high level of job satisfaction, then, the level of emotional exhaustion is lower among employees who have longer work experience.

In relation to salary of the employees, Willis Tower Watson conducted study (May 2016), specific to the Philippines, the country follows the Asia-Pacific trend, with low pay being the primary cause of stress. "Clearly there are a number of employees who are dealing with financial challenges where employers might be able to help beyond increases in pay. The good news is, there is a growing interest from employers in the Philippines to educate and encourage employees in adopting a financial well-being strategy," says Susan La Chica, Head of Health and Benefits for the Philippines at Willis Towers Watson.

\section{CONLCUSION}

Based on the findings of the study, the following conclusions were drawn:

1. The respondents in this study are between 20-29 years old, female, single, completed bachelor's degree, with 1-5 years of working experience, in the rank and file position, assigned in the dining area, and earn 5,000-10, 000 per month.

2. The respondents are sometimes bombarded with emotional exhaustion in terms of:

2.1. Negative thoughts and feelings with an overall weighted mean of 1.93 which when verbally interpreted is "Sometimes" (moderately stressful);

2.2. Time Pressure with an overall average of 1.92 which when verbally interpreted is "Sometimes" (moderately stressful);

2.3. Strained Relationship with an overall average of 1.93 which when verbally interpreted is "Sometimes" (moderately stressful); and

2.4. Counter Productive Work/Behavior with an overall weighted mean of 1.90 which when verbally interpreted is "Sometimes" (moderately stressful).

3. Length of service and monthly income has significant relationship with emotional exhaustion of the respondents.
4. An employee development program was proposed as an output of this study to promote holistic improvement of the employees in the hospitality and tourism industry. The program includes not just professional trainings and enhancement but also emotional wellness and psychological development.

\section{RECOMMENDATION}

Congruent to the findings and conclusions presented, the following recommendations are suggested:

1. Future researchers may consider older hospitality and tourism professionals as subjects of other studies related to this to find if their emotional exhaustion is higher than respondents with majority of younger professionals.

2. Owners and managers of hospitality and tourism industry in Cabanatuan City must devise a sensible scheme of salary and should adhere strictly with the promulgated rulings on incentives and benefits.

3. Employees of hospitality and tourism industry in Cabanatuan City must be provided with trainings, seminars, workshops or even leisure activities that will help improve their work performance and honed their skills and capabilities.

4. Managers must provide interventions and improved relationships of the employees among themselves.

\section{EMPLOYER'S PART TO THE DEVELOPMENT PROGRAM}

1. Intrinsic Motivation - Commendations and awards

2. Extrinsic Motivation -Salary increases, rewards and incentives

\section{REFERENCES}

[1] Gazzingan, L., et al. (2013). Psychology (Dimensions of the Human Mind), Malabon City, Philippines. Mutya Publishing House, Inc.

[2] Maslach, C., \& Leiter, M. P. (2007). Burnout. In G. Fink (Ed.), Encyclopedia of stress, 2nd ed. (358-362). Oxford, UK: Elsevier.

[3] Pinder, Craig C. (2014). Work Motivation in Organizational Behavior, Second Ed. (271. University of Victoria, British Columbia

[4] Beitler et al., "Conflict Management and Age in Service Professions" International Journal of Conflict Management

[5] CNN Philippines' Survey on Filipino Stressors, Rappler, 2015

[6] http://www.rappler.com/life-and-style/career/131527-willistowers-watson-survey-employee-stress-causes

[7] Erickson, Erick "Stages of Human Development" 
[8] Karatepe, Osman M. "The Effects of Selected Individual Characteristics on Frontline Employee Performance and Job Satisfaction" Tourism Management Volume 27, Issue 4 (2006)

[9] Kiliç, et.al. "The Relationship Between Professional Burnout and Job Satisfaction Levels of Employee: A Study into Employees in Hotel Enterprises", International Journal of Human Science (2011)

[10] Kogovsek et al. "Emotional Labour in Hospitality Industry: Literature Review" Quaestus Multidisciplinary Research Journal (2015)

[11] Leiter, M. P., \& Maslach, C. (1988). The Impact of Interpersonal Environment on Burnout and Organizational Commitment. Journal of Organizational Behavior, 9, 297-308

[12] ResearchGate (2008) professional network for researchers.

[13] Magpayo, "Cabanatuan Enjoys Economic Boom", Business Mirror, 2014 http://www.businessmirror.com.ph/2014/12/07/cabanatuanenjoys-economic-boom/

[14] O'Neill, J.W. et al "Effects of Organizational/Occupational Characteristics and Personality Traits on Hotel Manager Emotional Exhaustion" International Journal of Hospitality Management (2010)

[15] Pelit and Turkmen, "The Relationship Between Ethics and Burnout" 2008

[16] Philippine Statistics Authority

[17] Rathi et al., "Emotional Exhaustion and Work Attitudes: Moderating effect of personality among frontline hospitality employees Journal of Human Resources in Hospitality \& Tourism, 2016,

[18] Schaufeli, et al. "An Organisational And Social Psychological Perspective On Burnout And Work Engagement" http://www.beanmanaged.com/doc/pdf/arnoldbakker/articles/ articles_arnold_bakker_140.pdf

[19] Tourigny, L. et al. "Job Burnout among Airline Employees in Japan A Study of the Buffering Effects of Absence and Supervisory Support" International Journal of Cross Cultural Management 2005

[20] Varona, Federico, "Relationship Between Communication Satisfaction and Organizational Commitment In Three Guatemalan Organizations" The Journal of Business Communication, 1996

[21] Willis Watson Tower, Rappler 2016 http://www.rappler.com/life-and-style/career/131527-willistowers-watson-survey-employee-stress-causes 